\title{
Gonadothropin-releasing hormone agonist as a treatment of choice for central precocious puberty
}

\author{
Jose RL. Batubara \\ Pediatric Endocrinology, Pediatric Department FKUI - RSCM, Jakarta
}

\begin{abstract}
Abstrak
Pubertas prekoks didefinisikan sebagai perkembangan pubertas yang timbul lebih dini. Batasan usia pubertas prekoks ini didasarkan pada awitan pubertas pada populasi normal. Beberapa kriteria yang dipertimbangkan adalah ras, jenis kelamin, kondisi nutrisi, dan secular trend. Pada perempuan, pubertas prekoks didefinisikan sebagai perkembangan payudara yang timbul sebelum usia 8 tahun. Pada laki-laki, pubertas prekoks didefinisikan sebagai gonadarke atau pubarke sebelum usia 9 tahun. Perjalanan klinis pubertas prekoks bervariasi, mulai dari alternating, progresif lambat, dan progresif cepat. Bentuk pubertas prekoks sentral idiopatik progresif cepat harus diterapi karena mengakibatkan penutupan epifisis dini dan tinggi akhir pendek. Tujuan terapi adalah untuk menghentikan maturasi fisik, mencegah menarke lebih dini dan juga memperbaiki tinggi dewasa. Gonadotropin releasing hormone analogue adalah terapi pilihan untuk pubertas prekoks sentral. GnRHa memiliki efek supresif terhadap aksis pituitari-gonad sehingga mampu mensupresi sekresi LH. Hal ini menyebabkan estradiol dan testosteron berada pada level prepubertal. Terapi menggunakan GnRHa mengurangi ukuran payudara, rambut pubis, ukuran uterus dan ovarium pada anak perempuan, serta mengurangi ukuran testis pada anak laki-laki. Gonadotropin releasing hormone analogue efektif menghambat progresi perkembangan karakteristik seks sekunder, siklus menstruasi, menghambat perkembangan usia tulang, dan memperbaiki tinggi akhir. (Med J Indones 2010; 19:287-92)
\end{abstract}

\begin{abstract}
Precocious puberty is defined as pubertal development which occurs too early. The age limit in this term is based on the onset of puberty in normal population. Some points have to be taken into account, such as ethnicity, gender, nutritional conditions, and secular trends. In girls, precocious puberty is defined by breast development occured before 8 years old. In boys, precocious puberty is defined as gonadarche or pubarche before 9 years of age. The clinical course of precocious puberty varies widely, ranging from alternating, slowly progressive, and rapidly progressive form. The rapidly progressive forms of idiopathic central precocious puberty need to be treated because it may result in early epiphyseal closure and short final height, and also pyschosocial problems in the affected children and the family. The aims of treatment are to arrest physical maturation, prevent early menarche, and also improve adult height combined with normal body proportions. Gonadotropin releasing hormone analogue is the treatment of choice for central precocious puberty. Gonadotropin releasing horomone analogue has suppressive effect on the pituitarygonadal axis, therefore it suppresses LH secretion. This leads to the return of estradiol and testosterone to prepubertal levels. Treatment using gonadotropin releasing horomone analogue is shown to reduce breast size, pubic hair, ovarian and uterine size in girls, and decrease testicular size in boys. Gonadotropin releasing hormone analogue is effective in halting progression of secondary sexual characteristics development, presenting menstrual cycle, slowing bone-age advancement, and also improving final height. (Med J Indones 2010; 19:287-92)
\end{abstract}

Key words: gonadache, GRH analogue, pubarche , precocious puberty

Puberty is a period where full sexual maturation is achieved. Puberty includes process of growth, development, and maturation of primary sexual organs, as well as the development of secondary sexual characteristics. Precocious puberty is defined as pubertal development which occurs too early. The age limit in this term is based on the onset of puberty in normal population. Some points have to be taken into account, such as ethnicity, gender, nutritional conditions, and secular trends. ${ }^{1}$ In girls, precocious puberty is defined by breast development occured before 8 years old. In boys, precocious puberty is defined as gonadarche or pubarche before 9 years of Correspondence email to: joserlb@pacific.net.id age. ${ }^{2}$ However, in the past 2 centuries, cilincians have observed earlier sexual maturation in children. This prompt the need for evaluation on the current guidelines for the ages at which the cause of precocious puberty should be searched for. The Lawson Wilkins Pediatric Endocrine Society recommended the age limit for diagnosing precocious puberty to be lowered, that is 7 years old for white girls and 6 years old for black girls. No recommendation was made on the age limits for boys. ${ }^{3}$ Due to these differences, the age limits on defining precocious puberty are necessarily subjected to local assessment and regular revision. 
There are two types of precocious puberty, that is central and peripheral. Central precocious puberty arises from the early maturation of hypothalamic-pituitary axis. Peripheral precocious puberty arises from premature secretion of sex steroids from gonads or other sites, or also from exogenous exposure. Both etiologies and mechanisms differ, therefore the treatment options also differ. Central precocious puberty responds to the treatment with gonadotropin-releasing hormone analogue (GnRHa), while the treatment of peripheral precocious puberty depends on the underlying diseases. ${ }^{1}$

The clinical course of precocious puberty varies widely, ranging from alternating, slowly progressive, and rapidly progressive form. The rapidly progressive forms of idiopathic central precocious puberty need to be treated because it may result in early epiphyseal closure and short final height, and also pyschosocial problems in the affected children and the family. ${ }^{4,5}$ The aims of treatment are to arrest physical maturation, prevent early menarche, and also improve adult height combined with normal body proportions. ${ }^{5}$

\section{APROACHES TO PRECOCIOUS PUBERTY}

A thorough history must be obtained about the age at onset of pubertal development, the rate of progression of pubertal sings, the growth pattern during the last 6-12 months, the presence of any secondary sexual characteristics, and additional signs of puberty such as acne, oily skin, erections, nocturnal emissions in boys and vaginal discharge and menstrual bleedings in girl. Practitioners must also obtain data about any family history of precocicous puberty. Positive family history of precocious puberty might suggest familial cases of central precocious puberty. ${ }^{6}$ History of possible central nervous system dysfunsction, such as headache, increased head circumference, visual impairment, or seizure, must also be obtained. ${ }^{7}$

Physical examination includes pubertal stages according to Tanner and measurement of height, weight, and body proportions. All height data are then plotted into a growth curve. Height velocity is also calculated on the basis of the available height data. Most patients with central precocious puberty have a height velocity more than 75th centile. ${ }^{6}$ Assessment for signs of specific causes of precocious puberty is also important, such as hyperpigmented skin lesions, suggesting neurofibromatosis of the McCune Albright syndrome. Psychological evaluation may also be useful since precocious puberty has been associated with hight levels of anxiety in girls. ${ }^{7}$
Bone age is measured to determine the biological age. An x-ray of the nondominant hand and wrist is taken. If bone age (BA) is accelerated by more than 2 standard deviations of chronological age (CA) it is most likely that the child has precocious puberty ${ }^{6-8}$ Hormonal evaluation is also needed, including plasma sex steroids and a standard GnRH test (injection of GnRH $60 \mu \mathrm{g} /$ $\mathrm{m}^{2}$, then Level of luteinizing hormone (LH) and folicle stimulating hormone (FSH) is measured at 0 and 30 minutes). The GnRH test is important in determining the type of precocious puberty, wheather it is central or peripheral precocious puberty. Central precocious puberty is characterized by a pubertal response of $\mathrm{LH}$ to GnRH, with a predominant LH response compared to FSH response. The $\mathrm{LH}$ concentration can reach to $55 \%$ higher than the normal range in girls with central precocious puberty. Immunochemiluminometric (ICMA) assays can also be used to assess precocious puberty, since it is sensitive on detecting elevated basal serum gonadotropin levels. ${ }^{6}$

Elevated basal LH serum levels may be useful as a screening test for identifying patients with central precocious puberty, due to it's correlation with the elevated GnRH-stimulated LH. However, the GnRH test is still the most important test in working-up children suspected of having central precocious puberty. Patients should be reassessed after 3-6 months of follow up. All typical laboratory findings may not be present in every patient, therefore the diagnosis must be based on the clinical manifestations, rather than solely on the hormonal data. ${ }^{6}$

Pelvic ultrasound is helpful in work-up of girls with central precocious puberty. Volumes of ovaries and uterus are measured, then compared to the age-spesific reference data. The parameters used are volume of ovaries, uterine shape, length, fundal/cervical ratio, structure, as well as thickness or presence of the endometrium. Bilateral enlargement of ovaries is a reliable indicator of central precocious puberty. Pelvic ultrasound should not be used as the only diagnostic tool for diagnosing central precocious puberty. It is indicated to detect adrenal or ovarian tumours, or ovarian cysts. ${ }^{6,8}$

In every children with proven central precocious puberty, MRI of the central nervous system (CNS) is necessary, in order to exclude a CNS lesion as a cause.${ }^{6,8}$ Central precocious puberty may be the only presenting symptom of intracranial tumour or malformatioin. ${ }^{8,9}$ The most common CNS lesion that is associated with central precocious puberty is hypothalamic hamartoma. ${ }^{6}$ 


\section{TREATMENT}

Treatment of central precocious puberty differs from peripheral precocious puberty, due to the differences on the etiologies. It is important to differentiate these two types of precocious puberty, since both have different differential diagnosis and also fundamentally different treatments. Central precocious puberty responds to gonadotropin-releasing hormone agonistic analogues (GnRHa), while peripheral precocious puberty responds to diverse treatment dependent to the underlying disease. ${ }^{1}$

Indication for treatment of central precocious puberty varies according to the centers guidelines. However, there is a consensus that not all patients with central precocious puberty need medical intervention. The indication for treatment may be psychosocial/behavioural or auxological or both. Criteria for auxological indication includes complete and progressive central precocious puberty and abnormal height potential or deterioration of final height prediction. Treatment using GnRHa is not indicated in patients with slowly progressing central precocious puberty and uncompromised height potential. ${ }^{6}$

Table 1. Suggested indications for GnRH agonist treatment in children with central precocious puberty.

1. Complete precocious puberty

2. Pubertal LH level after GnRH stimulation and LH/FSH ratio after GnRH stimulation above diagnostic limit

3. Rapid pubertal development (i.e. progression from one pubertal stage to the next in a markedly shorter period of time than normal)

4. Abnormal height potential (either height prediction below 3rd centile/below target height range or height standard deviation score (SDS) for bone age below

5. Loss of height potential during follow-up

6. Psychosocial/behavioural reasons (there is no general agreement how to define these reasons: mental immaturity, emotional immaturity and behavioural disturbances may be considered as indications for treatment; the decision must be individualized

Central precocious puberty was used to be treated with cyproterone acetate or medroxyprogesterone. But due to their insufficient effects regarding hormonal suppression and auxological outcome, and also their potential for side-effects, treatment using both drugs had become obsolete. ${ }^{6}{ }^{60}$ Cyproterone acetate is still used in conjunction with GnRHa for cases in which puberty is well advanced and there is documented endometrial echo of more than $4 \mathrm{~mm}$ thickness. ${ }^{10}$ Nowadays, GnRHa is the treatment of choice for central precocious puberty. Gonadotropin releasing hormone analogues suppress gonadotropin pulsatility and secretion, and it blocks the GnRH receptor in the pituitary. Therefore it will suppress and regress sexual maturation. These medication are relatively free of side effects and effective. There are several ways on administration of GnRHa, such as daily subcutaneous injections, intranasal sprays 2-3 times a day, or by depot injections lasting for 1-3 months.

\section{Gonadotropin releasing hormone analogue as treatment of choice}

Gonadotropin releasing hormone analogues are synthetic derivatives of gonadotropin releasing hormone, hormone which is responsible for the release of LH and FSH. At least two alterations in chemical structure serve to enhance the biologic activity of $\mathrm{GnRH}$, they are subtitution of a D-amino acid for the glycine molecule at position 6 , and deletion of the glycine molecule at position 10. These substitutions make GnRHa resistant to degradation by circulating and tissue peptides, and also increase its affinity to the GnRH receptors. Gonadotropin releasing hormone analogues have biologic activity 60150 times more than native GnRH. ${ }^{11}$

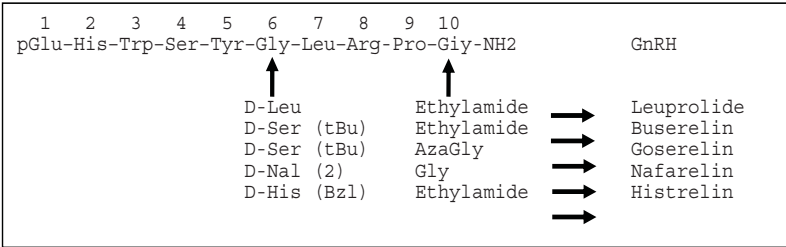

Figure 1. Amino acid structure of GnRH and substitutions that produce GnRHa

Gonadotropin Releasing Hormone Analogue is the treatment of choice for central precocious puberty. It is shown to preserve height potential within the genetically determined range in majority cases and also improve final height $(\mathrm{FH})$ compared with the target height $(\mathrm{TH})$ in patients with an unfavorable initial predicted adult height (PAH). Final height achieved is determined by several factors such as the age at onset of central precocious puberty, the initial bone age advancement, and the initial deficit in height potential compared to TH. ${ }^{5}$ Several preparations of GnRHa are currently available, such as leuprolide, triptorelin, histrelin, and buserelin.

Gonadotropin Releasing Horomone Analogue has suppressive effect on the pituitary-gonadal axis, therefore it suppress LH secretion. This lead to the return of estradiol and testosterone to prepubertal levels. Treatment using GnRHa is shown to reduce breast size, pubic hair, ovarian and uterine size in girls, and decrease testicular size in boys. ${ }^{6}$

Gonadotropin Releasing Hormone Analogue is effective in halting progression of secondary sexual characteristics 
development, presenting menstrual cycle, slowing boneage advancement, and also improving final height. ${ }^{4}$ Gonadotropin Releasing Hormone Analog desensitize the pituitary gonadotrope and supress $\mathrm{Gn}$ release by continous stimulation, therfore halting pubertal progression and decelerating bone growth and maturation. GnRHa needs to be given in the right dose continously, since intermittent administration could lead to stimulation of Gn release, whereas excessive dosing could result in side affects, that is growth deceleration or reduce bone density. ${ }^{10,12}$

Table 2. Types of gonadotropin releasing hormone analogue

\begin{tabular}{|c|c|c|}
\hline Drug & Formulation and Usually Recommended Dose & Side Effects and Cautions \\
\hline Depot GnRH agonists & & $\begin{array}{l}\text { Pain, erythema, inflamatory reaction, sterile abcess, } \\
\text { implant-site reaction, headaches, menopausal-like } \\
\text { symptoms, decreased bone density during treatment but } \\
\text { no long-term impairment documented after treatment is } \\
\text { discontinued }\end{array}$ \\
\hline Leuprorelin leuprolide & $\begin{array}{l}\text { 4-wk and } 12 \text {-wk preparations (SC or IM); US- } 0,3 \mathrm{mg} \text { / } \\
\text { kgBW every 4-wk; Europe-3,75mg every 4-wk or } \\
11,25 \text { mg every } 12 \text {-wk }\end{array}$ & \\
\hline Triptorelin & $\begin{array}{l}\text { 4-wk and } 12 \text {-wk preparations (IM); Europe- } 3-3,75 \mathrm{mg} \\
\text { every } 4 \text {-wk or } 11,25 \mathrm{mg} \text { every } 12 \text {-wk }\end{array}$ & \\
\hline Histrelin & 12-mo implants; US-50mg implant every 12-mo & \\
\hline $\begin{array}{l}\text { Rapid-acting GnRHa buserelin, } \\
\text { deslorelin, histrelin, leuprorelin, } \\
\text { leuprolide, nafarelin, triptorelin }\end{array}$ & Nasal spray or subcutaneous injections 1-3 times daily & $\begin{array}{l}\text { Difficulties with compliance; use usually limited to patients } \\
\text { with sterile abscesses from depot injections }\end{array}$ \\
\hline
\end{tabular}

There are some controversies regarding the use of GnRHa as a treatment for central precocious puberty. ${ }^{14}$ The first one concerns if treatment will increase final height in children whose onset of puberty is only slightly advanced than normal. The most common outcome reported after treatment with GnRHa is that improvement in final height over pretreatment predicted height, which approches but does not attain midparental height (MPH) ${ }^{14}$ But some investigators reported no improvement in final height in girls with the onset of puberty only slightly advanced. ${ }^{15,16}$

Studies report various outcome of treatment using GnRha. However, improvement in final height over pretreatment predicted height, which approaches the $\mathrm{MPH}$ is the most common. ${ }^{17} \mathrm{Klein}$ et al conducted a study on 98 children with precocious puberty who received long-term treatment with LHRHa. They showed that there was a dramatic increase in predicted height during treatment. Less delay in the onset and longer duration of treatment, as well as lower chronological and bone age ath the onset of treatment were associated with greater final height. Final height of all but nine children exceeded the pretreatment predicted height. Girls gained $9,8 \mathrm{~cm}$ over predicted height, and boys gained $12,5 \mathrm{~cm}$ over predicted height. Even girls with bone age greater than 13 years old at the start of treatment, had a significant improvement in adult height, although they were not as tall as the girls with a bone age less than 13 years old at the start of treatment. ${ }^{14}$
Gonadotropin releasing hormone analogue in depot formation, such as depot leuprolide (DL), gives advantages of consistent suppresion and convinient monthly administration. Dosing varies among health practitioners in many countries, ranging from 3,75 to $15 \mathrm{mg}$ with 4 weeks intervals or more frequent. In the United States, the recommended dose is $0,3 \mathrm{mg} / \mathrm{kg}$, with a dose range of 7,5-15 mg. In Asia and Europe, the standard dose is $3,75 \mathrm{mg}$ and the minimum supressive dose is $0,03 \mathrm{mg} / \mathrm{kg}$, one tenth US recommendation. Newer DL is delivered in a different slow release polymer, that is $11,25 \mathrm{mg}$ depot preparation given every 3 months. This new 3-month depot formulation has been used for treatment in adults, such as prostate cancer and endometriosis, and nowadays many pediatric endocrinologists in the US and Europe has started to use this preparation since it can reduce the burden of clinic visits. ${ }^{13}$

Duration of treatment is quite long in children with central precocious puberty, that is from the onset of CPP until the age at which puberty normally occurs. Children also often reacts emotionally strong to injection. These necessitate the development of a slow-release formulation so that it will increase the acceptability of treatment and also patients compliance. ${ }^{13,14}$ Carel JC stated that leuprorelin 3-month depot at a dose of 11.25 $\mathrm{mg}$ was effective in suppressing gonadotropin secretion in most children with central precocious puberty. The clinical signs of puberty stabilized and the growth rate decreased. The inhibition of LH responses was $95 \%$ 
with the 3-month depot. Estradiol levels were rapidly suppressed (nearly 100\%). ${ }^{13}$

Nasal spray therapy requires two or three daily doses. For a long period treatment, the effectiveness of nasal spray therapy is questioned, since it largely depends on patients compliance. Its absorption also depends on the physiologic condition of nasal mucose membrane. Rhinitis will cause absorption of GnRHa to decrease. Long term usage was reported to cause nasal irritation. Nasal spray therapy is reported to be not as effective as long action intramuscular or subcutaneous treatment in hypothalamic suppression, and also on achievement of a taller final height. Therefore nasal spray therapy is no longer used in daily practices, and replaced by other long-acting GnRHa. ${ }^{18}$

Study by Badaru A et al compared all three doses of DL, that is 3,75 mg once a month, 7,5 mg once a month, and 11,25 mg every 3 months. This study showed that the $3,75 \mathrm{mg}$ DL dose and 11,25 mg-3 months lead to higher levels of LH and FSH compared to the standard dose of 7,5 $\mathrm{mg}$. The rise in Gn levels due to transition from 7,5 to $3,75 \mathrm{mg}$ is caused directly by the dose reduction. Poorer Gn suppression by $11,25 \mathrm{mg}-3$ months dose is still a question, wheter it is caused by the lower total dose or by the frequency of delivery. The implications of variable degress of $\mathrm{Gn}$ suppression achieved through different DL dosing regimens is not known. Other then cost and convinience reason, the administration of DL should consider the most effective puberty suppression for optimal long-term growth. ${ }^{12}$

The standard preparation of GnRHa is in a parenteral preparations. Injections are painful, and since the treatment of precocious puberty is often quite long and the need for monthly clinic visits, this can be a reaseon for poor patients' complience. To improve this condition, a subcutaneous implant was developed. It releases GnRHa histrelin at an average of $65 \mathrm{ug} /$ day. ${ }^{4}$ Histrelin implant is usually used to suppress LH and testosterone in metastatic prostate cancer. Chertin et al proposed that this implant preparation could also be use for children with central precocious puberty. ${ }^{19}$

Hirsch et al conducted a study to compare parenteral and implant preparations of GnRHa. In 15 months long observation, histrelin implant produced more complete LH suppression than that achieved by the IM agonist. There was no clinical progression of puberty and in some breast development regressed. Growth velocity increased initially for chronical age, then decreased during treatment. Skeletal maturation progressed more slowly during treatment. Insertion of the implant was performed under local anesthesia, and no patients reported pain nor discomfort. Patients and families expressed strong preference with this implant preparation since it did not need monthly clinical visits and it was far less painful. With these benefits, implant preparation might improve patients' compliance and also have economic benefits since time lost from fork for the parents would be reduced. ${ }^{4}$

\section{Monitoring and discontinuation}

Regular evaluation is necessary for monitoring the adequacy and efficacy of the treatment. Height, weight, growth velocity, and Tanner staging of puberty must be measured. Other measurements such as bone age, basal sex steroid, LH, FSH, and GnRH test are also recommended to monitor the proper suppression of hormones within the first 3 months and then every 6 months. Adequacy of treatment is considered when the estradiol level becomes prepubertal or when the peak LH is below 2,3 IU/L after a classical GnRH test, or below 6,6 IU/L 2 hors after administration of DL. Discontinuation of GnRHa therapy mainly depends upon the primary goals of therapy, one of which is prevention of short adult height. The parameters for this goal is chronological age of 11 years, or bone age of 12-12,5 years of age. Other goals include decreasing psychosocial distress and facilitation of care of the developmentally delayed child. ${ }^{20}$

After cessation of treatment, gonadal function is soon reactivated. Study by Pasquino AM et al showed that the reactivation of the hypothalamo-pituitary-gonadal axis was prompt and similar for all subjects, as either gonadotropin and estrogen levels or completion of uterine and ovarian development. ${ }^{21}$ The mean time for onset of menstruation after discontinuation of therapy is 16 months (ranging from 2 to 61 months) with regular cycles and six pregnancies with normal offspring. ${ }^{20,21}$ This shows that GnRHa therapy is reversible for the reproductive system.

\section{Adverse effects}

Administration of GnRHa produces relatively minimal adverse reactions. Some adverse effects associated with administration of GnRHa are pain at injection sites, headaches and menopausal symptoms, such as hot flushes. Sterile abscesses at injection sites occur in 3-13\% patients. Treatment with GnRHa causes fat mass to increase, while lean mass and bone density tend to decrease. These have raised concerns aboutpossible risk of obesity and osteporosis, 
but longitudinal studies show that the prevalence of obesity does not increase during and after treatment, bone density is also normal after cessation of treatment. ${ }^{7}$

In conclusion, precocious puberty is defined by breast development in girls occured before 8 years old, or gonadarche or pubarche in boys before 9 years of age. Central precocious puberty may result in early epiphyseal closure and short final height, and also pyschosocial problems in the affected children and the family. The aims of treatment are to arrest physical maturation, prevent early menarche, and also improve adult height combined with normal body proportions. Gonadotropin Releasing Hormone Analogue is the treatment of choice for central precocious puberty. Gonadotropin Releasing Hormone Analogue is effective in halting progression of secondary sexual characteristics development, presenting menstrual cycle, slowing bone-age advancement, and also improving final height. After discontinuation of therapy, GnRHa is reversible for the reproductive system, therefore it does not have any effects on normal puberty and fertility.

\section{REFERENCES}

1. Partsch CJ, Sippell WG. Pathogenesis and epidemiology of precocious puberty. Effects of exogenous oestrogens. Human Reproduction Update 2001;7(3):292-302

2. Parent AS, Teilmann G, Juul A, Skakkebaek NE, Toppari J, Bourguignon JP. The timing of normal puberty and the age limits of sexual precocity: variations araound the world, secular trends, anda changes after migration. Endocrine Reviews 2003;24(5):668-93

3. Teilmann G, Pedersen CB, Jensen TK, Skakkebek NE, Juul A. Prevalence and incidence of precocious pubertal development in Denmark: an epidemiologic study based on national registries. Pediatrics 2005;116(6):1323-8

4. Hirsch HD, Gillis D, Strich D, Chertin B, Farkas A, Lindenberg T. The histrelin implant: a novel treatment for central precocious puberty. Pediatrics 2005;116; 798-802

5. Heger S, Partsch CJ, Sippell WG. Long-term outcome after depot gonadotropin-releasing hormone agonist treatment of central precocious puberty: final height, body proportions, body composition, bone mineral density, and reproductive function. J Clin Endocrinol Metab. 1999;4(12):4583-90

6. Partsch CJ, Heger S, Sippell WG. Management and outcome of central precocious puberty. Clinical Endocrinology 2002;56(2):129-48
7. Carel JC, Leger J. Precocious puberty. N Engl J Med 2008;358:2366-77

8. Fahmy JL, Kaminsky CK, Kaufman F, Nelson MD, Parisi MT. The radiological approach to precocious puberty. Br J Radiol. 2000;73:560-7

9. Chemaitilly W, Trivin C, Adan L, Gall V, Sainte-Rose C, Brauner R. Central precocious puberty: clinical and laboratory features. Clinical Endocrinology. 2001;54:289-94

10. Stanhope R, Traggiai C. Precocious puberty (complete, partial). Sultan C (ed): Pediatric and Adolescent Gynecology. Evidence-Based Clinical Practice. Endocr Dev. Basel, Karger, 2004, vol 7, pp 57-65

12. Casper RF. Clinical uses of gonadotropin-releasing hormone analogues. Can Med Assoc J. 1991;144(2):153-8

13. BadaruA, Wilson DM, Bachrach LK, Fechner P, Gandrud LM, Durham E, et al. Sequential comparisons of one-month and three-month depot leuprolide regimens in central precocious puberty. J Clin Endocrinol Metab. 2006;91(5):1862-7

14. Carel JC, Lahlou N, Jaramillo O, Montauban V, Teinturier C, Colle M. Treatment of central precocious puberty by subcutaneous injections of leuprorelin 3-month depot (11.25mg). J Clin Endocrinol Metab. 2002;87(9):4111-6

15. Klein KO, Barnes KM, Jones JV, Feuillan PP, Cutler GB. Increased final height in precocious puberty after long-term treatment with LHRH agonists: The National Institutes of Health experience. J Clin Endocrinol Metab. 2001;86(10):4711-6

16. Micillo M, Salerno M, Officioso A, et al. Near final height after GnRH agonist treatment in central precocious puberty. J Pediatr Endocrinol Metab. 2000;13(Suppl 1):787-90

17. Cassio A, Cacciari E, Balsamo A, Bal M, Tassinari D. Randomized trial of LHRH analogue treatment on final height in girls with onset of puberty aged 7.5-8.5 years. Arch Dis Child. 1999; 81:329-32

18. Bouvattier C, Coste J, Rodrigue D, et al. Lack of effect of GnRH agonists on final height in girls with advanced puberty: a randomized long-term pilot study. J Clin Endocrinol Metab. 1999; 84:3575-8

19. DiazA,Danon M. Recentadvances in the diagnosis and treatment of precocious puberty. Indian J Pediatr. 2000;67(3):211-5

20. Chertin B, Spitz IM, Lindenberg T, et al. An implant releasing the gonadotropin hormone-releasing hormone agonist histrelin maintains medical castration for up to 30 months in metastatic prostate cancer. J Urol. 2000;163:838-44

21. Kim HS. Clinical application of gonadotropin-releasing hormone analogs in children and adolescents. Korean J Pediatr. 2010;53(3):294-9

22. Pasquino AM, Pucarelli I, Accardo F, Demiraj V, Segni M, Di Nardo R. Long-term observation of 87 girls with idiopathic central precocious puberty treated with gonadotropinreleasing hormone analogs: impact on adult height, body mass index, bone mineral content, and reproductive function. J Clin Endocrinol Metab. 2007;93(1):190-5 